\title{
Pengaruh Model Pembelajaran Problem Based Learning (PBL) Berbasis Kearifan Lokal Terhadap Sikap Sosial Dan Berfikir Kritis Pada Mata Pelajaran Matematika
}

\author{
Dian Soraya ${ }^{1}$, I Nyoman Jampel ${ }^{2}$, Komang Sujendra Diputra ${ }^{3}$ \\ ${ }^{123}$ Prodi Pendidikan Guru Sekolah Dasar, Jurusan Pendidikan Dasar, Universitas Pendidikan \\ Ganesha, Singaraja, Indonesia \\ e-mail: \{diansoraxx@gmail.com, jampel@undiksha.ac.id, komang \\ sujendra.diputra@undiksha.ac.id\}@undiksha.ac.id
}

\begin{abstract}
Abstrak
Penelitian ini bertujuan untuk mengetahui pengaruh antara model pembelajaran Problem Based Learning (PBL) berbasis kearifan lokal terhadap sikap sosial dan berfikir kritis pada mata pelajaran matematika siswa kelas V SD Gugus Singosari Kecamatan Pekutatan Kabupaten Jembrana Tahun Pelajaran 2018/2019. Jenis penelitian ini adalah penelitian eksperimen semu dengan rancangan Non Equivalent Posttest Only Control Group Design. Populasi penelitian ini adalah seluruh siswa kelas V SD di Gugus Singosari, Kecamatan Pekutatan, Kabupaten Jembrana. Sampel diambil dengan cara random sampling melalui teknik undian. Instrumen pengumpulan data yang digunakan dalam penelitian ini adalah kuesioner sikap sosial dan tes uraian berfikir kritis. Data dianalisis menggunakan statistik deskriptif dan uji MANOVA. Hasil penelitian menunjukkan bahwa terdapat perbedaan yang signifikan sikap sosial siswa dan berfikir kritis secara parsial dan simultan dengan taraf signifikansi $0,000<0,05$. Dengan demikian model pembelajaran Problem Based Learning (PBL) berbasis kearifan lokal berpengaruh positif terhadap sikap sosial dan berfikir kritis siswa pada mata pelajaran matematika siswa kelas V SD Gugus Singosari Kecamatan Pekutatan Kabupaten Jembrana Tahun Pelajaran 2018/2019 Saran bagi penelitian selanjutnya diharapkan hasil penelitian ini dapat digunakan kembali pada pelajaran lain.
\end{abstract}

Kata kunci: PBL,kearifan lokal, sikap sosial, berfikir kritis

\begin{abstract}
This study aims to find out to find out the influence of Problem Based Learning (PBL) learning models based on local wisdom on social attitudes and critical thinking on math subjects in fifth grade students of SD Gugus Singosari, Pekutatan Subdistrict, Jembrana District, 2018/2019 Academic Year. This type of research is quasi-experimental research with the design of Non Equivalent Posttest Only Control Group Design. The population of this study was all fifth grade elementary school students in Singosari Cluster, Pekutatan District, Jembrana Regency. Samples are taken by random sampling through lottery techniques. The instruments of data collection used in this study were social attitude questionnaires and critical thinking description tests. Data were analyzed using descriptive statistics and MANOVA test. The results showed that there were significant differences in students' social attitudes and critical thinking partially and simultaneously with a significance level of $0.000<0.05$. Thus the local wisdom-based Problem Based Learning (PBL) learning model has a positive effect on students' social attitudes and critical thinking on mathematics subjects in fifth grade students of SD Gugus Singosari, Pekutatan Subdistrict, Jembrana Regency 2018/2019 Academic Year Suggestions for future research are expected to reused in another lesson.
\end{abstract}

Keywords: PBL, local wisdom, social attitudes, critical thinking. attitude 


\section{Pendahuluan}

Matematika merupakan salah satu mata pelajaran yang wajib dipelajari. Matematika sangat diperlukan baik untuk kehidupan sehari-hari maupun dalam menghadapi kemajuan IPTEK sehingga matematika perlu dibekalkan kepada setiap peserta didik sejak SD, bahkan sejak TK.

Pelajaran matematika sangat penting digunakan dalam kehidupan sehari-hari. Melalui pelajaran matematika, siswa dibekali dengan kemampuan berpikir logis, analitis, sistematis, kritis, kreatif, serta kemampuan bekerjasama, sehingga siswa dapat memahami dan memecahkan masalah dengan baik.

Dalam memecahkan masalah matematika hal yang terpenting yang harus ditekankan pada siswa adalah kemampuan berfikir kritisnya. Menurut Walker (dalam Intan, 2019) menyatakan bahwa berfikir kritis merupakan suatu proses yang dilalui dari proses pemecahan masalah dan kolaborasi dengan tujuan agar peserta didik memperoleh pengetahuan pengetahuan baru. Menurut Damawati (2013) Berfikir kritis adalah berfikir logis dan reflektif yang dipusatkan pada keputusan apa yang diyakini atau dikerjakan. Menurut Karim (2011) kemampuan berpikir kritis dapat dikembangkan melalui pembelajaran matematika di sekolah atau pun perguruan tinggi, yang menitik beratkan pada sistem, struktur, konsep, prinsip, serta kaitan yang ketat antara suatu unsur dan unsur lainnya

Dari pendapat tersebut dapat disimpulkan bahwa berfikir kritis adalah suatu proses berfikir yang dilalui dalam memecahkan masalah sehingga memperoleh pengetahuan yang baru. Berfikir kritis merupakan salah satu dari tuntutan pendidikan abad 21. Peserta didik dalam pembelajaran abad ke-21 perlu keterampilan yang dinamakan Learning and innovation skills (keterampilan belajar dan berinovasi) meliputi 4C (Communication, Collaboration, Critical Thinking and Problem Solving, dan Creativity and Innovation). Keterampilan abad ke-21 atau diistilahkan dengan 4C merupakan kemampuan sesungguhnya ingin dituju dengan Kurikulum 2013.

Istilah 4C ini dapat dipaparkan sebagai berikut, Communication (komunikasi) adalah sebuah kegiatan mentransfer sebuah informasi baik secara lisan maupun tulisan. Collaborative (kolaborasi) adalah kemampuan berkolaborasi atau bekerja sama, saling bersinergi, beradaptasi dalam berbagai peran dan tanggungjawab; bekerja secara produktif dengan yang lain; menempatkan empati pada tempatnya; menghormati perspektif berbeda. Critical thinking and Problem Solving (berpikir kritis dan pemecahan masalah) adalah kemampuan untuk memahami sebuah masalah yang rumit, mengkoneksikan informasi satu dengan informasi lain, sehingga akhirnya muncul berbagai perspektif, dan menemukan solusi dari suatu permasalahan. Creativity and Innovation (Kreativitas dan inovasi) adalah kemampuan untuk mengembangkan, melaksanakan, dan menyampaikan gagasan-gagasan baru kepada yang lain; bersikap terbuka dan responsif terhadap perspektif baru dan berbeda.

Sejauh ini, sekolah belum sepenuhnya melatih hal tersebut di atas, yang dituntut dalam pembelajaran abad 21. Hal ini terbukti dari masih rendahnya kemampuan berpikir kritis siswa yang dilihat dari perolehan hasil belajar siswa yang dapat dilihat dari hasil survey PISA (Programme for International Student Assessment). Hasil survey PISA menunjukkan bahwa skor rata-rata literasi matematika masih di bawah skor rata-rata negara-negara yang mengikuti survey (PISA, 2015). Hal ini menunjukkan bahwa posisi literasi matematika siswa Indonesia masih di bawah literasi matematika negara-negara di dunia pada umumnya.

Mata pelajaran matematika tidak hanya semata - mata melatih kemampuan berfikir kritis pada siswa namun juga mampu menumbuhkan sikap sosial siswa. Sikap sosial siswa akan tumbuh ketika siswa melakukan interaksi dengan lingkungan sekitarnya. Oleh karena itu sikap sosial siswa bisa dikatakan mempunyai peranan yang sangat penting dalam proses pembelajaran. Menurut Ahmadi (2007:149) sikap sosial adalah kesadaran individu yang menentukan perbuatan yang nyata dalam kegiatan - kegiatan sosial. Menurut Sugiantari, (dalam Kusuma, 2017) sikap sosial adalah kesadaran individu yang menentukan perbuatan yang nyata, yang berulang-ulang terhadap objek sosial.

Berdasarkan pendapat diatas dapat disimpulkan bahwa sikap sosial adalah kesadaran individu untuk melakukan perbuatan dalam kegiatan sosial. Dari berbagai aspek yang mempengaruhi sikap sosial adalah aspek budaya yang paling besar mempengaruhi terbentuknya sikap orang tersebut. Budaya yang mewarnai sikap anggota masyarakat, serta memberikan corak pengalaman individu - individu yang menjadi kelompok masyarakat.

Berdasarkan hasil observasi yang dilakukan dalam proses pembelajaran Matematika kelas V SD di Gugus Singosari, Kecamatan Pekutatan, Kabupaten Jembrana pada tanggal 28 
November 2017 di peroleh hasil yaitu, 1) dalam proses pembelajaran guru masih menggunakan pembelajaran yang bersifat konvensional sehingga siswa merasa bosan saat mengikuti pembelajaran. Guru yang seharusnya sebagai fasilitator bagi siswa hendaknya mampu menciptakan suasana belajar yang menarik yaitu dengan menciptakan pembelajaran yang inovatif dan menantang bagi siswa yang mampu membangkitkan semangat belajar siswa. 2) dalam proses pembelajaran guru hanya menilai dari aspek kognitif siswa saja. Hal ini membuat siswa hanya mengejar nilai saja tanpa mementingkan proses kerjanya. Jika dicermati dalam observasi sebagian besar siswa berlomba - lomba untuk memperoleh nilai yang bagus dengan cara menyontek pekerjaan temannya yang mengakibatkan suasana kelas menjadi gaduh. Suasana seperti itu yang sangat jarang di perhatikan oleh guru. 3) ketika guru mengajar dikelas, tidak pernah guru mengaitkan pembelajaran dengan lingkungan sekitarnya. Hal inilah yang mengakibatkan siswa hanya mengenal konsep matematika secara abstrak bukan secara kongkret.

Upaya yang dapat dilakukan untuk mengatasi masalah tersebut yaitu dengan dengan menggunakan model pembelajaran Problem Based Learning (PBL) Berbasis Kearifan Lokal. Menurut Gunantara (2014) model pembelajaran Problem Based Learning (PBL) adalah suatu pendekatan pembelajaran dengan membuat konfrontasi kepada pebelajar dengan masalahmasalah praktis atau pembelajaran yang dimulai dengan pemberian masalah dan memiliki konteks dengan dunia nyata. Model pembelajaran Problem Based Learning (PBL) atau dikenal dengan model pembelajaran berbasis masalah merupakan model pembelajaran yang menggunakan permasalahan nyata yang ditemui di lingkungan sebagai dasar untuk memperoleh pengetahuan dan konsep melalui kemampuan berpikir kritis dan memecahkan masalah (Fakhriyah, 2014). Oleh karena itu model oembelajaran Problem Based Learning (PBL) mampu meningkatkan sikap sosial dan berfikir kritis siswa pada mata pelajaran matematika.

Dalam menerapkan model pembelajaran Problem Based Learning (PBL) perlu dikaitkan dengan lingkungan sekitar siswa. Lingkungan sekitar siswa yang dimaksudkan adalah kearifan lokal. Gobyah (dalam Arnyana, 2014) mengemukakan kearifan lokal adalah kebenaran yang telah mentradisi atau ajeg dalam suatu daerah. Kearifan lokal merupakan perpaduan antara nilai - nilai suci Tuhan dan berbagai nilai budaya yang ada. Kearifan lokal terbentuk sebagai keunggulan budaya masyarakat setempat maupun kondisi geografis dalam arti luas. Kearifan lokal merupakan produk budaya masa lalu yang patut secara terus-menerus dijadikan pegangan hidup. Meskipun bernilai lokal tetapi nilai yang terkandung di dalamnya dianggap sangat universal. Untuk meningkatkan sikap sosial dan berfikir kritis siswa sangat diperlukan model pembelajaran berbasis kearifan lokal. Selain siswa mampu memahami materi pelajaran yang diarkan siswa juga mampu mengenal lingkungan sekitar mereka.

Tujuan penelitian ini adalah Untuk mengetahui pengaruh aantara model pembelajaran Problem Based Learning (PBL) berbasis kearifan lokal terhdap sikap sosial dan berpifikir kritis secara parsial dan simultan pada mata pelajaran matematika kelas V SD Gugus Singosari Kecamatan Pekutatan Kabupaten Jembrana Tahun Pelajaran 2018/2019.

\section{Metode}

Penelitian ini merupakan jenis penelitian eksperimen semu (quasi experiment). Desain yang digunakan dalam penelitian ini adalah Non-equivalent Post-test Only Group Design. Populasi dalam penelitian ini adalah seluruh siswa kelas V SD di Gugus Singosari, Kecamatan Pekutatan, Kabupaten Jembrana. Banyaknya populasi dalam penelitian ini adalah 191 siswa. Populasi yang ada dipilih menggunakan teknik pengundian (random sampling) untuk menentukan sampel yang digunakan dalam penelitian ini. Teknik pengundian ini dilakukan karena tidak memungkinkan diadakannya pengambilan subjek penelitian secara acak dari populasi yang ada, karena subjek (siswa) secara alami telah terbentuk dalam satu kelompok (satu kelas). Teknik random sampling dilakukan dengan sistem undian.

Berdasarkan hasil pengundian, diperoleh dua kelas sampel yaitu siswa kelas V SD Negeri 2 Medewi ang berjumlah 27 siswa sebagai kelas eksperimen. Dan siswa kelas V SD Negeri Medewi yang berjumlah 31 siswa sebagai kelas kontrol. Kelas eksperimen diberikan perlakuan dengan menerapkan model pembelajaran Problem Based Learning (PBL) berbasis kearifan lokal dan kelas kontrol diberikan menggunakan pembelajaran konvensional. 
Dalam penelitian ini, perlakuan diberikan pada kelas eksperimen dengan menggunakan model pembelajaran Problem Based Learning (PBL) berbasis kearifan lokal. Sedangkan pada kelas kontrol tidak diberikan perlakuan khsusus artinya tidak digunakan pembelajaran literasi, tetapi pembelajaran yang diterapkan di kelompok kontrol adalah pembelajaran yang telah biasa guru terapkan dalam proses pembelajaran. Setelah perlakuan baik kelas kontrol maupun kelas eksperimen diberikan post-test untuk mengetahui sikap sosial dan berfikir kritis masing-masing kelompok.

Data yang dikumpulkan dalam penelitian ini adalah skor sikap sosial dan berfikir kritis siswa dalam mata pelajaran matematika siswa kelas V SD. Metode pengumpulan data yang digunakan dalam penelitian ini adalah instrumen kuesioner dan tes.

Instrumen pengumpulan data yang digunakan dalam penelitian ini adalah berupa kuisioner sikap sosial dan tes uraian berfikir kritis. Untuk menentukan butir soal instrumen tersebut layak untuk diberikan terhadap kelompok sampel terlebih dahulu dilakukan validasi instrumen. validasi kuesioner sikap sosial dan berfikir kritis meliputi: validitas isi menggunakan rumus Gregory validitas butir tes menggunakan rumus korelasi product moment, dan reliabilitas KR-20.

Analisis data yang digunakan dalam penelitian ini menggunakan ANAVA A untuk menguji hipotesis 1 dan 2 serta MANOVA untuk menguji hipotesis 3 . Sebelum dilakukan uji hipotesis terlebih dahulu dilakukan uji prasyarat analisis yang meliputi uji normalitas sebaran data, uji homogenitas varian, dan uji korelasi antar dua variabel. Seluruh pengujian yang dilakukan menggunakan bantuan SPSS 21.0 for windows.

\section{Hasil dan Pembahasan}

Berdasarkan hasil analisis deskriptif yang telah dilakukan tentang sikap sosial dan berfikir kritis siswa, menunjukkan bahwa pada sikap sosial Rata-rata skor sikap sosial siswa yang mengikuti model pembelajaran Problem Based Learning (PBL) berbasis kearifan lokal adalah 112,30, berada pada interval 100 s/d 120 dengan klasifikasi baik dan Rata-rata skor Sikap Sosial siswa yang mengikuti pembelajaran konvensional adalah 89,59 , berada pada interval 80 s/d 100 dengan kategori cukup. Hal tersebut berarti sikap sosial siswa pada kelompok eksperimen lenih besar daripada sikap sosial siswa pada kelompok kontrol

Sedangkan pada berfikir kritis memiliki rata-rata skor berpikir kritis siswa yang mengikuti mode pembelajaran Problem Based Learning (PBL) berbasis kearifan lokal adalah 194,56, berada pada interval $180 \mathrm{~s} / \mathrm{d} 240$ dengan kategori sangat baik. Sedangkan, rata-rata skor berpikir kritis siswa yang mengikuti pembelajaran konvensional adalah 140 berada pada interval $140 \mathrm{~s} / \mathrm{d} 180$ dengan kategori baik. Hal tersebut berarti berfikir kritis siswa pada kelompok eksperimen lebih besar dapada berfikir kritis siswa kelompok kontrol.

Setelah dilakukan analisis deskriptif pada hasil belajar IPA dan sikap sosial siswa kelas eksperimen dan kelas kontrol kemudian dilanjutkan uji hipotesis. Sebelum uji hipotesis dilakukan terlebih dahulu dilakukan uji prasyarat yaitu uji normalitas, homogenitas dan korelasi antar variabel terikat. Berdasarkan uji normalitas data menggunakan Kolmogorov Smirnov dengan bantuan SPSS 21.0, yang disajikan pada Tabel 1.

Tabel 1. Rekapitulasi Hasil Pengujian Normalitas Sebaran Data dengan Uji KolmogorovSmirnov

\begin{tabular}{|c|c|c|c|c|}
\hline \multirow{2}{*}{$\begin{array}{l}\text { Variabel yang di } \\
\text { ikur }\end{array}$} & \multirow[t]{2}{*}{ Model Pembelajaran } & \multicolumn{3}{|c|}{$\begin{array}{l}\text { Kolmogorov- } \\
\text { Smirnov(a) }\end{array}$} \\
\hline & & Statistik & Df & Sig. \\
\hline \multirow{2}{*}{ Sikap Sosial } & $\begin{array}{l}\text { Model Pembelajaran Problem Based Learning } \\
\text { (PBL) Berbasis Kearifan Lokal }\end{array}$ & 0,147 & $\begin{array}{l}2 \\
7\end{array}$ & $\begin{array}{r}0,1 \\
38\end{array}$ \\
\hline & Pembelajaran Konvensional & 0,108 & 31 & 0,200 \\
\hline \multirow{2}{*}{ Berfikir Kritis } & $\begin{array}{l}\text { Model Pembelajaran Problem Based Learning } \\
\text { (PBL) Berbasis Kearifan Lokal }\end{array}$ & 0,093 & $\begin{array}{l}2 \\
7\end{array}$ & $\begin{array}{l}0,2 \\
00^{*}\end{array}$ \\
\hline & Pembelajaran Konvensional & 0,114 & 31 & $0,200 *$ \\
\hline
\end{tabular}


TSCJ, Vol 1 No 2, Tahun 2018

p-ISSN : 2615-4692 e-ISSN : 2615-6105

Berdasarkan tabel 1 di atas, menunjukkan bahwa statistik Kolmogorov-Smirnov memiliki angka signifikansi $>0,05$. Maka semua sebaran menurut model Pembelajaran Problem Based Learning (PBL) Berbasis Kearifan Lokal berdistribusi normal.

Uji Prasyarat yang kedua adalah uji homogenitas varians. Pada uji homogenitas dilakukan dengan dua cara yaitu secara bersama - sama menggunakan uji Box'M dan secara sendiri - sendiri menggunakan Levene's Test dengan bantuan SPSS 21.0 for windows yang disajikan pada Tabel 2 uji Box'M dan Tabel 3 uji Levene's Test.

Tabel 2 Hasil Analisis Uji Box’s M

\begin{tabular}{cc}
\hline Box's $M$ & 28.667 \\
\hline F & 9.184 \\
df1 & 3 \\
df2 & 1589781.900 \\
Sig. & 0,085 \\
\hline
\end{tabular}

Tabel 3. Hasil Analisis Uji Levene's Test

\begin{tabular}{llrrrr}
\hline & F & df1 & df2 & \multicolumn{1}{l}{ Sig. } \\
\hline Sikap Sosial & 11.587 & 1 & 56 & 0,071 \\
Berfikir Kritis & 14.720 & 1 & 56 & 0,120 \\
\hline
\end{tabular}

Berdasarkan hasil analisis data di atas, angka signifikansi yang dihasilkan dari sikap sosial maupun berfikir kritis siswa secara bersama - sama maupun sendiri - sendiri yaitu $>0$, 05. Dengan demikian dapat disimpulkan analisis hasil sikap sosial dan berfikir kreatif siswa adalah homogen sehingga uji hipotesis menggunakan analisis MANOVA (Multivariate Analysis of Varians) dapat dilanjutkan.

Uji prasyarat yang ketiga adalah uji korelasi antar dua variabel. Uji Korelasi dihitung dengan bantuan SPSS 21.0 for windows yang hasilnya adalah 0,705 (dibulatkan menjadi 0,7 ) yang artinya bernilai lebih besar dari 0,705 . Jadi ini menunjukkan bahwa tidak ada korelasi antar variabel terikat dan uji MANOVA layak untuk dilakukan.

Setelah diperoleh hasil uji prasyarat analisis data, dilanjutkan dengan pengujian hipotesis 1 dan 2 menggunakan uji ANAVA A dengan bantuan program SPSS versi 21.0 for windows. Berdasarkan hasil perhitungan pada hipotesis pertama dan kedua disajikan pada Tabel 4 dan Tabel 5.

Tabel 4. Hasil Uji Hipotesis Pertama

\begin{tabular}{lcrrrr}
\hline \multicolumn{1}{c}{ Sikap sosial } & $\begin{array}{l}\text { Sum of } \\
\text { Squares }\end{array}$ & df & $\begin{array}{c}\text { Mean } \\
\text { Square }\end{array}$ & $\boldsymbol{F}$ & Sig. \\
\hline Between Groups & 7446,425 & 1 & 7446,425 & 61,585 & 0,000 \\
\hline Within Groups & 6771,178 & 56 & 120,914 & & \\
\hline
\end{tabular}

Tabel 5. Uji Hipotesis Kedua

\begin{tabular}{lrrrrr}
\hline \multicolumn{1}{c}{ Berfikir kritis } & Sum of Squares & Df & Mean Square & \multicolumn{1}{c}{$\boldsymbol{F}$} & \multicolumn{1}{c}{ Sig. } \\
\hline Between Groups & 42951,213 & 1 & 42951,213 & 1491,485 & 0,000 \\
Within Groups & 1612,667 & 56 & 28,798 & & \\
Total & 44563,879 & 57 & & & \\
\hline
\end{tabular}


Berdasarkan data hasil perhitungan ANAVA A pada hipotesis pertama pada Tabel 4 diperoleh $F_{\text {hit }}$ sebesar 61,585 dengan angka signifikansi 0,000 dengan taraf signifikansi sebesar 0,05 . Signifikansi (sig) lebih kecil dari $0,000(0,000<0,05)$. Dengan demikian $\mathrm{H}_{0}$ ditolak dan $\mathrm{H}_{1}$ diterima. Berarti terdapat perbedaan yang signifikan sikap sosial antara siswa yang dibelajarkan dengan model Pembelajaran Problem Based Learning (PBL) Berbasis Kearifan Lokal, dan siswa yang dibelajarakan dengan pembelajaran konvensional. Sementara untuk hasil uji hipotesis kedua yang disajikan pada Tabel 5 diperoleh $F_{\text {hit }}$ sebesar 1491,485 dengan angka signifikansi 0, 000 dengan taraf signifikansi sebesar 0,05. Signifikansi (sig) lebih kecil dari $0,000(0,000<0,05)$. Dengan demikian $\mathrm{H}_{0}$ ditolak dan $\mathrm{H}_{1}$ diterima. berarti terdapat perbedaan yang signifikan berfikir kritis antara siswa yang dibelajarkan dengan model Pembelajaran Problem Based Learning (PBL) Berbasis Kearifan Lokal, dan siswa yang dibelajarakan dengan pembelajaran konvensional. Dan untuk uji hipotesis ketiga disajikan pada Tabel 6 .

Tabel 6. Hasil Analisis Uji Hipotesis Ketiga Multivariate Test

\begin{tabular}{llrcrrc}
\hline & Effect & Value & $F$ & Hypothesis df & Error df & \multicolumn{1}{l}{ Sig. } \\
\hline \multirow{4}{*}{ Intercept } & Pillai's Trace & 0,999 & $30711,497^{\mathrm{b}}$ & 2,000 & 55,000 & 0,000 \\
& Wilks' Lambda & 0,001 & $30711,497^{\mathrm{b}}$ & 2,000 & 55,000 & 0,000 \\
& Hotelling's Trace & 1116,782 & $30711,497^{\mathrm{b}}$ & 2,000 & 55,000 & 0,000 \\
& Roy's Largest Root & 1116,782 & $30711,497^{\mathrm{b}}$ & 2,000 & 55,000 & 0,000 \\
& Pillai's Trace & 0,966 & $777,386^{\mathrm{b}}$ & 2,000 & 55,000 & 0,000 \\
& Wilks' Lambda & 0,034 & $777,386^{\mathrm{b}}$ & 2,000 & 55,000 & 0,000 \\
& Hotelling's Trace & 28,269 & $777,386^{\mathrm{b}}$ & 2,000 & 55,000 & 0,000 \\
& Roy's Largest Root & 28,269 & $777,386^{\mathrm{b}}$ & 2,000 & 55,000 & 0,000 \\
\hline
\end{tabular}

Dari hasil perhitungan hipotesis ketiga pada Tabel 6 di atas diperoleh nilai $F_{\text {hit }}$ pada Pillae Trace, Wilks' Lambda, Hotelling's Trace, Roy's Largest sebesar 777,386 dengan memiliki angka signifikan 0,000 atau $<0,05$. Berdasarkan analisis data tersebut sehingga hipotesis nol $\left(\mathrm{H}_{0}\right)$ ditolah dan hipotesis alternatif $\left(\mathrm{H}_{1}\right)$ diterima. Jadi, dari hasil hipotesis ketiga yaitu terdapat perbedaan secara signifikan sikap sosial dan berfikir kritis yang dibelajarkan dengan model Pembelajaran Problem Based Learning (PBL) Berbasis Kearifan Lokal dan dengan pembelajaran konvensional diajarkan secara simultan antara siswa di SD Gugus Singosari Kecamatan Pekutatan Kabupaten Jembrana Tahun Pelajaran 2018/2019..

Hasil analisis hipotesis pertama menemukan bahwa terdapat perbedaan yang signifikan sikap sosial siswa antara siswa yang dibelajarkan dengan model pembelajaran Problem Based Learning ( $P B L$ ) berbasis kearifan lokal dan siswa yang dibelajarkan tidak dengan model pembelajaran Problem Based Learning (PBL) berbasis kearifan lokal pada mata pelajaran matematika siswa kelas V SD Gugus Singosari Kecamatan Pekutatan Kabupaten Jembrana Tahun Pelajaran 2018/2019 pada taraf signifikansi 0,05. Untuk mengetahui besarnya pengaruh antara model pembelajaran Problem Based Learning (PBL) dan model pembelajaran konvensional, dapat dilihat dari nilai rata-rata sikap sosial antara kedua kelompok. Rata-rata sikap sosial kelompok eksperimen adalah 112,30. Sedangkan, rata-rata Sikap Sosial kelompok kontrol adalah89,58. Hal ini berarti, rata-rata skor kelompok eksperimen lebih besar dari ratarata skor kelompok kontrol $\left(\mathrm{M}_{\text {eksperimen }}>\mathrm{M}_{\text {kontrol }}\right)$. Ini berarti model pembelajaran Problem Based Learning (PBL) berpengaruh positif terhadap sikap sosial siswa.

Hasil analisis ini juga dibuktikan secara langsung melalui pengamatan ketika proses pembelajaran berlangsung. Pada kelas eksperimen yang diberikan perlakuan berupa model pembelajaran Problem Based Learning (PBL) berbasis kearifan lokal dalam mata pelajaran matematika membuat siswa lebih bersemangat dan membiasakan siswa untuk membaca, menggali informasi dan menemukan konsep serta memecahkan masalah dengan sendirinya, Siswa menjadi mandiri dan pemahaman siswa juga semakin meningkat karena dalam pembelajaran siswa mendengarkan dan mendapat pengalaman langsung serta membuat analisa sendiri terkait dengan materi yang diajarkan, Sementara pada kelas kontrol yang menggunakan pembelajaran konvensional siswa terlihat pasif dan siswa hanya menunggu penjelasan dari guru tanpa mau mencari sendiri tentang materi yang sedang diajarkan. Siswa tidak aktif dalam menjawab pertanyaan guru, karena siswa merasa jenuh untuk membaca materi pelajaran yang menyebabkan sikap sosial siswa pada kelas kontrol rendah. 
Dalam mata pelajaran matematika berbasis kearifan lokal sangat tepat di terapkan. Dengan diajarkannya mata pelajaran matematika mampu mengajarkan siswa tentang sikap yang baik dan benar. Sejalan dengan pendapat yang disampaikan oleh Elmubarok (2009:47) "sikap adalah suatu bentuk evaluasi perasaan dan kecenderungan potensial untuk bereaksi yang merupakan hasil interaksi antara komponen kognitif, afektif dan konatif yang saling bereaksi didalam memahami, merasakan dan berprilaku terhadap suatu objek". Dengan model pembelajaran Problem Based Learning (PBL) demikian dapat dikatan sikap adalah penjelmaan dari paradigma yang pada giliranya akan melahirkan nilai-nilai yang dianut seseorang.

Sikap yang dianut oleh banyak orang yang disebut sikap sosial. "Sikap sosial adalah sikap yang ada pada kelompok orang yang ditujukan pada suatu objek yang menjadi perhatian seluruh anggota kelompok tersebut" (Sarwono 2017:201). Menurut Virani, dkk (2016) "Sikap sosial adalah sikap yang menentukan cara individu untuk menghadapi individu lainnya dalam masyarakat terhadap objek-objek sosial yang ada". Teori tersebut didukung oleh penelitian yang dilakukan oleh Gede Elga Pranata, Desak Putu Parmiti, dan I Md. Citra Wibawa tahun 2015 melakukan penelitian tentang perbedaan sikap sosial dan hasil belajar IPS siswa secara bersama-sama antara kelompok siswa yang mengikuti pembelajaran dengan menggunakan Model Pembelajaran Kooperatif tipe Group Investigation dan kelompok siswa yang mengikuti Model pembelajaran konvensional pada siswa kelas V SD gugus IV kecamatan Klungkung Tahun ajaran 2014/2015 $(\mathrm{P}<0,05)$.

Berdasarkan hasil analisis dan penelitian pendukung yang sesuai dengan penelitian ini, dapat disimpulkan bahwa model pembelajaran Problem Based Learning (PBL) berpengaruh terdapat sikap sosial siswa Kelas V SD Gugus Singosari Kecamatan Pekutatan Kabupaten Jembrana Tahun Pelajaran 2018/2019.

Hasil penelitian hipotesis kedua menemukan bahwa terdapat perbedaan yang signifikan berfikir kritis siswa antara siswa yang dibelajarkan dengan model pembelajaran Problem Based Learning (PBL) berbasis kearifan lokal dan siswa yang dibelajarkan tidak dengan model pembelajaran Problem Based Learning (PBL) berbasis kearifan lokal pada mata pelajaran matematika siswa kelas V SD Gugus Singosari Kecamatan Pekutatan Kabupaten Jembrana Tahun Pelajaran 2018/2019 pada taraf signifikansi 0,05. Untuk mengetahui besarnya pengaruh antara model pembelajaran Problem Based Learning (PBL) dan model pembelajaran konvensional, dapat dilihat dari nilai rata-rata berfikir kritis antara kedua kelompok. Rata-rata berfikir kritis kelompok eksperimen adalah 194,56. Sedangkan, berfikir kritis kelompok kontrol adalah 140. Hal ini berarti, rata-rata skor kelompok eksperimen lebih besar dari rata-rata skor kelompok kontrol $\left(M_{\text {eksperimen }}>M_{\text {kontrol }}\right)$. Ini berarti model pembelajaran Problem Based Learning $(P B L)$ berbasis kearifan lokal berpengaruh positif terhadap berfikir kritis siswa.

Berdasarkan hasil analisis tersebut, tentu saja terdapat berbagai hal yang menyebabkan terjadinya perbedaan berfikir kritis matematika secara signifikan antara siswa yang belajar dengan model pembelajaran Problem Based Learning (PBL) berbasis kearifan lokal dan siswa yang belajar dengan menggunakan model pembelajaran konvensional. Perbedaan tersebut disebabkan oleh hal-hal berikut. Pertama, adanya masalah yang berupa soal-soal yang disajikan dalam pembelajaran membuat siswa aktif secara fisik dan mental untuk melatih berpikir kritis siswa dalam memecahkan suatu masalah. Siswa tampak gigih dan analitis untuk dapat mencari penyelesaian masalah. Siswa juga dituntut untuk dapat menggali kembali pengetahuan mereka mengenai konsep-konsep yang sesuai dengan permasalahan yang disajikan. Selain itu siswa juga memiliki kebebasan dan keleluasaan untuk mengembangkan kreativitas dan keterampilan berpikir kritisnya, sehingga berpikir kritis siswa menjadi lebih optimal.

Kedua, pembelajaran menggunakan model pembelajaran Problem Based Learning (PBL) berbasis kearifan lokal melatih siswa menyelesaikan masalah-masalah yang berkaitan dengan soal-soal pemecahan masalah. Siswa termotivasi dan antusias mengerjakan soal-soal dengan menggunakan tahapan - tahapan pembelajaran PBL yang di dalamnya berisi istilah - istilah kearifan lokal seperti sangkel dan ngayah. Selain itu, siswa dapat menemukan konsep materi pembelajaran berupa pemecahan maslah sendiri. Hal ini terlihat dari, kemampuan siswa dalam menjawab soal-soal dan memecahkannya agar memperoleh jawaban yang benar. Hal ini sesuai dengan pendapat Hudojo (2005: 125), yang menyatakan bahwa "pemecahan masalah merupakan suatu proses penerimaan masalah sebagai tantangan untuk menyelesaikan masalah tersebut". Setiap kelompok bersaing agar bisa menyelesaikan kartu masalah yang diperoleh. Adanya persaingan tersebut, memacu kemampuan berpikir mereka dari masing masing anggota kelompok. Sehingga, berpikir kritis siswa menjadi lebih optimal. 
Berdasarkan hasil analisis dan temuan lain yang sesuai dengan penelitian ini, dapat disimpulkan bahwa model pembelajaran Problem Based Learning (PBL) berbasis kearifan lokal berpengaruh terhadap berfikir kritis siswa pada siswa Kelas V SD Gugus Singosari Kecamatan Pekutatan Kabupaten Jembrana Tahun Pelajaran 2018/2019.

Hasil analisis hipotesis ketiga diperoleh nilai $F$ Pillae Trace $(F=777,386)$, Wilks' Lambda $(\mathrm{F}=777,386)$, Hotelling's Trace $(\mathrm{F}=777,386)$, Roy's Largest Root $(\mathrm{F}=777,386)$ yang seluruhnya memiliki signifikan 0,000 atau $<0,05$, maka hipotesis ke tiga diterima yaitu terdapat perbedaan yang signifikan sikap sosial dan berfikir kritis siswa secara simultan dengan model pembelajaran Problem Based Learning (PBL) berbasis kearifan lokal.

Dari hasil analisis yang di lakukan dan dibuktikan melalui pengamatan dalam pembelajaran bahwa model pembelajaran Problem Based Learning (PBL) berbasis kearifan lokal berpengaruh terhadap sikap sosial dan berfikir kritis siswa secara bersama - sama, model pembelajaran Problem Based Learning (PBL) berbasis kearifan lokal menekankan kepada proses keterlibatan siswa secara penuh untuk dapat menemukan pengetahuan baru melalui kegiatan percobaan.

Berdasarkan hasil analisis dan temuan lain yang sesuai dengan penelitian ini, dapat disimpulkan bahwa model pembelajaran Problem Based Learning (PBL) berbasis kearifan lokal berpengaruh secara simulatan terdapat sikap sosial dan berifir kritis siswa Kelas V SD Gugus Singosari Kecamatan Pekutatan Kabupaten Jembrana Tahun Pelajaran 2018/2019.

\section{Simpulan dan Saran}

Berdasarkan paparan hasil penelitian dan pembahasan di atas, dapat disimpulkan hasil penelitian ini yaitu model pembelajaran Problem Based Learning (PBL) berbasis kearifan lokal dalam pembelajaran matematika berpengaruh terhadap sikap sosial, model pembelajaran Problem Based Learning (PBL) berbasis kearifan lokal berpengaruh terhadap berfikir kritis, dan model pembelajaran Problem Based Learning (PBL) berbasis kearifan lokal berpengaruh terhadap sikap sosial dan berfikir kritis siswa yang dibelajarkan secara bersama - sama.

Bertolak dari hasil penelitian, dapat diajukan beberapa saran yaitu penelitian tentang pembelajaran literasi bisa dikembangkan lebih lanjut lagi dengan melakukan penelitian kembali yang diinovasikan dengan wawasan yang lebih inovatif sehingga membuat pembelajaran lebih bervariasi, menyenangkan, dan membuat siswa lebih memahami materi ajar yang disampaikan guru. Diterapkannya model pembelajaran Problem Based Learning (PBL) berbasis kearifan lokal agar siswa mengikuti langkah-langkah pembelajaran dengan baik, sehingga dapat meningkatkan sikap sosial dan berfikir kritis siswa serta menuju pencapaian kompetensi yang maksimal. Terbatasnya waktu penelitian menyebabkan penelitian hanya dilakukan pada mata pelajaran matematika saja. Dengan demikian, hasil penelitian ini dapat dijadikan referensi awal bagi peneliti lain yang ingin meneliti lebih lanjut dalam skala luas dan variabel yang beragam.

\section{Daftar Pustaka}

Ahmadi, H.A. 2007. Psikologi Pendidikan. Jakarta: Rineka Cipta.

Arnyana, Ida Bagus Putu. 2014. Peranan Budaya Bali Dalam Mengembangkan Pendidikan Karakter di Sekolah. Seminar Nasional FMIPA UNDIKSHA IV Tahun 2014 Tersedia pada:

Arikunto, Suarsimi. 2005. Dasar - Dasar Evaluasi Pendidikan. Jakarta: Bumi Aksara

Astawan, I Gede. 2010. Model-model Pembelajaran Inovatif. Singaraja: Undiksha.

Asmani, Jamal Ma'mur. 2012. Pendidikan Berbasis Keunggulan Lokal. Yogyakarta: Diva Press.

Atmadja, A.T., Darmawan, N.A.S., Adi, K. and Saputra, K., 2015. Pengaruh Implementasi Good Corporate Governance Dan Proteksi Awig-Awig Terhadap Kinerja Lembaga Perkreditan Desa (LPD) Dengan Budaya Menyama Braya Sebagai Variabel Moderasi (Studi Pada Lpd Se-Kabupaten Buleleng). Prosiding Konfrensi Regional Akuntansi II, Malang-Jawa Timur. 
Dantes, N. 2017. Desain Eksperimen dan Analisis Data. Singaraja: PT Rajagrafindo Persada.

Darmawati, N.P.A., Tegeh, I.M. dan Suarni, N.K., 2013. Pengaruh Model Pembelajaran Children Learning In Science Berbantuan Metode Talking Stick Terhadap Sikap IImiah Dan Penguasaan Konsep IPA Kelas V. MIMBAR PGSD Undiksha, Volume 1, Nomor 1. Tersedia pada https://ejournal.undiksha.ac.id/index.php/JJPGSD/article/view/789. (diakses tanggal 27 Februari 2019).

Dewi, M.T.P., Pudjawan, K. dan Riastini, P.N., 2014. Pengaruh metode edutainment terhadap hasil belajar IPA siswa kelas V SD di Gugus XV kecamatan Buleleng tahun ajaran 2013/2014. MIMBAR PGSD Undiksha, Volume 2, Nomor 1. Tersedia pada https://ejournal.undiksha.ac.id/index.php/JJPGSD/article/view/1975. (diakses pada tanggal 28 Februari 2019).

Eliza, R., Fauzan, A., Lufri, L. and Yerizon, Y., 2019. The Validity of Realistic Problem Based Learning Model Development of Mathematics Learning in Vocational High School (SMK). In International Conference on Islamic Education (ICoIE 2018). Atlantis Press.

Ennis, R. H., W. L. Gardiner, R. Morrow, D. Paulus, dan L. Ringel. 1964. The Cornell ClasReasoning Test, Form X. Champaign: Illinois Critical Thinking Project, Department of Edicational Policy Studies, University of Illinois at Urbana-Champaign.

Fakhriyah, F., 2014. Penerapan Problem Based Learning dalam Upaya Mengembangkan Kemampuan Berpikir Kritis Mahasiswa. Jurnal Pendidikan IPA Indonesia, 3(1). Tersedia pada https://journal.unnes.ac.id/nju/index.php/jpii/article/view/2906/2934. (diakses pada tanggal 26 Februari 2019).

Gusviani, Evi. 2017. Analisis Kemunculan Sikap Spiritual dan Sikap Sosial dalam Kegiatan Pembelajaran IPA Kelas IV SD yang Menggunakan KTSP dan Kurikulum 2013. EDUHUMANIORA, Volume 7, Nomor 2. Tersedia pada http://ejournal.upi.edu/index.php/eduhumaniora/article/view/5127. (diakses tanggal 27 Februari 2019).

Gunantara, G., Suarjana, I.M. dan Riastini, P.N., 2014. Penerapan model pembelajaran problem based learning untuk meningkatkan kemampuan pemecahan masalah matematika siswa kelas V. MIMBAR PGSD Undiksha, Volume 2, Nomor 1. Tersedia pada https://ejournal.undiksha.ac.id/index.php/JJPGSD/article/view/2058/1795. (diakses pada tanggal 26 Februari 2019).

Hasratuddin. Pembelajaran Matematika Sekarang dan yang akan Datang Berbasis Karakter. Tersedia pada digilib.unimed.ac.id>FullText.

Karim, A., 2011. Penerapan Metode Penemuan Terbimbing Dalam Pembelajaran Matematika Untuk Meningkatkan Pemahaman Konsep Dan Kemampuan Berpikir Kritis Siswa Sekolah Dasar. Jurnal Pendidikan, 1(1), pp.21-32. Tersedia pada http://jurnal.upi.edu/file/3-Asrul Karim.pdf. (diakses tanggal 26 Februari 2019).

Kusuma. 2014. Pengaruh Model Pembelajaran Problem BasesLearning Terhadap hasil Belajar IPA Pada Siswa Kelas V Semester Ganjil Di Gugus XIV SD Kecamatan Buleleng Kabupaten Buleleng Tahun Pelajaran 2013/2014. E-journal PGSD Vol: 2 No: 1. PGSD Undiksha. (hlm 1-10). 
TSCJ, Vol 1 No 2, Tahun 2018

p-ISSN : 2615-4692 e-ISSN : 2615-6105

Kusuma, Putu Indra. 2017. Pengaruh Model Pembelajaran Resolusi Konflik Terhadap Hasil Belajar PKn Ditinjau Dari Sikap Sosial Siswa Kelas V SD Gugus Kolonel I Gusti Ngurah Rai Denpasar Utara. Jurnal IImiah Pendidikan dan Pembelajaran PPs, Volume 14, Nomor 3. Tersedia pada https://ejournal.undiksha.ac.id/index.php/JIPP/article/view/11988. (diakses pada tanggal 20 Januari 2019).

Marhaeni. 2013. Landasan dan Inovasi Pembelajaran. Singaraja: Universitas Pendidikan Ganesha.

PISA 2015. Tersedia pada: https://www.oecd.org/pisa/PISA-2015-Indonesia.pdf Shoimin, A. 2014. $68 \quad$ Model Pembelajaran Inovatif dan Kurikulum 2013. Yogyakarta: AR-RUZZ Media.

Suharman,Edy. 2017. Peran Guru IPS Sebagai Pendidik dan Pengajar dalam Meningkatkan Sikap Sosial dan Tanggung Jawab Sosial Siswa SMP. Jurnal Pendidikan IPS, Volume 4, Nomor 1. Tersedia pada https://journal.uny.ac.id/index.php/hsipi/article/view/8660. (diakses pada tanggal 20 Januari 2019).

Suamba, I Nyoman. 2012. Wujudkan Sikap Menyama Braya dengan Pikiran yang Positif. Majalah Hindu, Raditya.

Suara, dkk. 2016. Pengaruh Model Pembelajaran Problem Based Learning Berbantuan Media Gambar Terhadap Keterampilan Membaca Bahasa Indonesia.E-journal PGSD Vol:4 No: 1. PGSD Undiksha. (hlm 1-10).

Surya, Hendra. 2011. Strategi Jitu Mencapai Kesuksesan Belajar. Jakarta: Gramedia.

Undang - Undang Republik Indonesia Nomor 20 Tahun 2003. Sistem Pendidikan Nasional.

Wiranata. 2017. Pengaruh Model Pembelajaran Problem Based Learning Terhadap Hasil Belajar Ipa Siswa Kelas V Sd, E-Journal PGSD, Vol:5. No: 2. (hlm 1-10). Tersedia pada https://ejournal.undiksha.ac.id/index.php/JJPGSD/article/download/10739/6845. (diakses pada tanggal 28 Februari 2019).

Wiyana, Ida Bagus Gede. 2012. Menghormati Kearifan Lokal Sebagai Landasan Strategis Mewujudkan Makna Menyama Braya Sebagai Penguatan Jati Diri Bangsa. www.wordpress.com, diakses tanggal 1 April 2019 